\title{
The Effect of Service Quality on Satisfaction and Impact on Loyalty User Transportation Service CV Sempati Star Medan-Banda Aceh
}

\author{
Finta Aramita \\ Master of Management \\ Faculty of Economics and Business \\ Universitas Sumatera Utara \\ Medan, Indonesia \\ finta.aramita@yahoo.com
}

\author{
Endang Sulistya Rini \\ Departement of Management \\ Faculty of Economic and Business \\ Universitas Sumatera Utara \\ Medan, Indonesia \\ endangsulistyarini@yahoo.co.id
}

\author{
Beby Karina Fawzeea Sembiring \\ Departement of Management \\ Faculty of Economic and Business \\ Universitas Sumatera Utara \\ Medan, Indonesia \\ biring.beby@gmail.com
}

\begin{abstract}
The growing and increasing role of the service sector in the future is mainly driven by rapid advances in telecommunications and information technology. The challenge for the service management today is how to integrate all the elements that exist in the consumer service to fit the strategy of the company's operations that have been set. This study aims to determine the effect of quality of service to satisfaction and its impact on the loyalty of transport users cv. Sempati star majanan medan - banda aceh. Type of research is quantitative research using survey method. The number of samples in this study as many as 100 respondents. The sampling technique used is accidental sampling. Methods of data collection is done by observation, interview, questionnaire. Data analysis method is done by data analysis of path diagram (path analysis). The results showed that tangible partially have a positive and significant influence on satisfaction, responsiveness partially have a positive and significant influence on satisfaction, partial reliability has a positive and significant impact on satisfaction, assurance partially have a positive and significant influence on satisfaction, Partial has a positive and significant influence on satisfaction, partial satisfaction has a positive and significant impact on loyalty of users of CV bus services. Sempati Star, while simultaneously obtained results that the quality of service (Tangible, Responsiveness, Reliability, Assurance, emphaty) and satisfaction together have a positive and significant influence on loyalty The results of research using path analysis showed that tangible directly affect loyalty, responsiveness influence Directly to loyalty, reliability directly affects loyalty, assurance directly affects loyalty, empaty indirectly affects loyalty, that satisfaction is an intervening variable.
\end{abstract}

Keyword:Quality of service; Tangible; Responsiveness; Reliability; Assurance; Emphaty; Satisfaction; Loyalty.

\section{INTRODUCTION}

The growing and increasing role of the service sector in the future is mainly driven by rapid advances in telecommunications and information technology. Currently services account for almost 1/3 (one third) of world trade volume and $3 / 5$ (three fifths) of foreign direct investments (FDI) (Tjiptono, 2007: 4). Theodore Levitt observes that the more sophisticated a generic product (eg automobiles, photocopiers and computers), sales are increasingly dependent on the quality and availability of customer service, delivery facilities, repair and maintenance, application assistance, operator training, and warranty fulfillment.
The challenge for today's service management is how to integrate all the elements in customer service to fit the strategy of the company's established operations. Today's customers are flooded with many choices of goods and services they can buy. Customers make choices based on their perception of quality, service and value. Companies must understand the determinants of value and customer satisfaction (Abdullah and Tantri, 2012: 44).

CV. Sempati Star under the auspices of Sepakat Group headquartered in Medan, Sempati Star, which is incorporated in the parent company Sepakat Group, brought in a dozen MB OH 1836 enliven the Banda Aceh - Medan trajectory with the O500R fleet. After playing 1626, 1830 and O500R 1836 as the initial trigger. Now Sempati Star pioneered SCANIA into the realm of Aceh. With K360, Sempati Star is ready to wade through Medan - Banda Aceh. In addition to Medan - Banda Aceh, Sempati Star spread its wings by opening the route Medan - Takengon and Medan - Meulaboh. While Banda Aceh - Tapaktuan played microbus fleet. Every week or every day, residents of Banda Aceh city who travel to Medan city for various reasons, such as shopping, business, college, and even some who work in the city of Medan.

Data on the number of passengers of Bus Sempati Star Medan Banda-Aceh destination can be seen from Table 1 below:

TABLE 1

NUMBER OF PASSENGERS BUS SEMPATI STAR MEDAN BANDA ACEH 2013 - 2016

\begin{tabular}{|l|c|c|c|c|c|}
\hline $\begin{array}{l}\text { Bus Class } \\
\text { Type }\end{array}$ & $\begin{array}{c}\text { Ticket } \\
\text { Price }\end{array}$ & $\mathbf{2 0 1 3}$ & $\mathbf{2 0 1 4}$ & $\mathbf{2 0 1 5}$ & $\mathbf{2 0 1 6}$ \\
\hline $\begin{array}{l}\text { Patas } \\
\text { Executive }\end{array}$ & 170.000 & 19.700 & 24.000 & 30.000 & $\begin{array}{c}35.00 \\
0\end{array}$ \\
\hline $\begin{array}{l}\text { Super } \\
\text { Executive }\end{array}$ & 180.000 & 8.000 & 11.300 & 13.400 & $\begin{array}{c}15.00 \\
0\end{array}$ \\
\hline Patas VIP & 200.000 & 12.000 & 14.600 & 15.500 & $\begin{array}{c}17.80 \\
0\end{array}$ \\
\hline Super VIP & 210.000 & 10.000 & 12.800 & 13.600 & $\begin{array}{c}14.20 \\
0\end{array}$ \\
\hline $\begin{array}{l}\text { Kelas } \\
\text { Nonstop }\end{array}$ & 250.000 & 7.900 & 10.600 & 11.200 & $\begin{array}{c}12.70 \\
0\end{array}$ \\
\hline $\begin{array}{l}\text { Double } \\
\text { Decker }\end{array}$ & 430.000 & 9.800 & 12.300 & 13.600 & $\begin{array}{c}14.50 \\
0\end{array}$ \\
\hline Amount & & $\mathbf{6 9 . 4 1 3}$ & $\mathbf{8 7 . 6 1 4}$ & $\mathbf{9 8 . 7 1 5}$ & $\begin{array}{c}\mathbf{1 0 9 . 2} \\
\mathbf{0 0}\end{array}$ \\
\hline
\end{tabular}

Source: Information Section CV Sempati Star (2016)

In Table 1 , in the last four years the number of passengers occupy the star has increased the number of passengers on each type of bus offered by Sempati Star, the 
passengers are satisfied or loyal to the bus occupied star. This increase can be caused by service, satisfaction given by Sempati Star Medan to service user so that impact to loyalitas passenger always use transportation service CV. Sempati Star.

TABLE 2

COMPARISON OF NUMBER OF ACEH BUS PASSENGERS PURPOSE

MEDAN - BANDA ACEH YEAR 2013 - 2016

\begin{tabular}{|l|c|c|c|c|}
\hline \multicolumn{1}{|c|}{ Bus Name } & $\mathbf{2 0 1 3}$ & $\mathbf{2 0 1 4}$ & $\mathbf{2 0 1 5}$ & $\mathbf{2 0 1 6}$ \\
\hline Sempati Star & 69.413 & 87.614 & 98.715 & $\begin{array}{c}109.20 \\
0\end{array}$ \\
\hline Putra Pelangi & 89.000 & 80.000 & 65.000 & 59.800 \\
\hline Kurnia & 60.000 & 58.000 & 40.000 & 39.000 \\
\hline PMTOH & 76.000 & 70.000 & 60.000 & 62.900 \\
\hline $\begin{array}{l}\text { Harapan } \\
\text { Indah }\end{array}$ & 86.000 & 78.700 & 71.900 & 70.000 \\
\hline \multicolumn{4}{|l|}{} \\
\hline
\end{tabular}

Source: PO Bus (2016)

Table 2 shows the ratio of the number of passengers per different bus types to Medan-Banda Aceh destination; competition also occurs between the Aceh Buses that serve Medan-Banda Aceh. The Bus Company is fighting for the sympathy of service users to offer their buses of good quality. So in the competition, the transport service users who will choose which bus they will ride.

To see further and deeper what are the problems faced by passengers Bus Sempati Star pre-survey results from 30 (thirty) passengers Bus Sempati Star, the result of observation and interview the average passenger said that sempati star has not maximized its service because the waiting room very small and not clean, at the time of ticket payment or ticket repayment when the passengers are always queuing and there is no queue number, so many other passengers who grab a queue, then sempati star also not on time in the jolt, written in the ticket at 20.30 so the departure delayed until 21:00 - 21:30 hours so that passengers are bored to wait, buses also like to raise passengers in the middle of the road, disturbing the comfort of passengers, then also provided blanket feels not smelled or smelled unpleasant, meaning the blanket was never washed, then passengers another meng the air conditioner leaked and dripped the water and hit the passenger head causing uncomfortable passengers on the way to rest, another problem faced by passengers was the security of passenger's belongings, as there had been a loss of passenger goods in the bus, given not in accordance with customer expectations. Plus ticket purchasing system that has not been online so difficult for passengers in ordering, although listed in phone number in ordering but not yet able to give easiness and comfort of passengers when booking ticket, conventional ticket booking not yet online, bus driver often raise passengers in so that to obtain accurate information about the arrival and departure of the bus, do not have information system that at any time can be known by prospective passengers regarding the arrival and departure of buses and bus plates Sempati Star. Besides, although there are still passengers who are not satisfied with the quality of service CV. Sempati Star, they keep repeatedly using bus sempati on the grounds of a comfortable bus, easy chair, many choices of departure time, and fast service and the driver always prioritizes passenger safety, and get to the destination just in time rarely late so it is more convenient to use bus sempati, compared to other buses although there is a sense of dissatisfaction in the quality of service.

Simple survey results conducted on 27 and 28 March 2017 on community responses to CV Sempati Star service quality in 2016 (see Table 3) indicate that most customers are not satisfied with the quality of CV Sempati Star service.
TABLE 3

PRE-SURVEY DATA QUALITY SERVICE CV SEMPATI STAR

\begin{tabular}{|c|c|c|}
\hline Statement & Yes & No \\
\hline Tangible & $30 \%$ & $70 \%$ \\
\hline Responsiveness & $43 \%$ & $57 \%$ \\
\hline Reliability & $33 \%$ & $67 \%$ \\
\hline Assurance & $37 \%$ & $63 \%$ \\
\hline Empathy & $54 \%$ & $46 \%$ \\
\hline
\end{tabular}

Source: Pre Survey, 2016 (Data Processed)

Table 3 states for the quality of service with the number of 21 respondents $(70 \%)$, the percentage that does not agree with the physical condition of the vehicle. Percentage of employees who do not agree CV Sempati Star quick response in melayanai customers as much as $57 \% \%$ (17 respondents). The percentage that does not agree with CV Sempati's reliability in service is $67 \%$ (20 respondents) and the percentage that do not agree with security using CV Sempati Star service is 63\% (19 respondents). And the percentage does not agree with the friendliness and politeness of employees CV Sempati Star as much as $46 \%$ (14 respondents). This shows the quality of service for CV Sempati Star service is considered not good for the users of bus services Sempati Star.

\section{LITERATURE REVIEW}

\section{A. Quality of Service}

Whether you realize it or not, every business is essentially a service business (every business is a service business). Within each organization, for example, the term internal customer (employee) is known. In other words each individual or department acts as a provider or recipient of services of individuals / other departments. The quality of service provided to external customers is highly dependent on the quality of relations and work of all internal customers. Therefore customer satisfaction and loyalty will materialize effectively if internal customer satisfaction and loyalty are created.

Tjiptono (2012: 3) explains that service (service) is doing something for others. As a service the service generally reflects intangible products or specific sectors such as, education, healthcare, telecommunications, transportation, insurance and so forth. As a service, the term service implies everything that a certain party does (individuals or groups) to other parties (individuals and groups).

Based on this definition, the quality of service is determined by the ability of the company to meet customer needs and desires in accordance with customer expectations.

\section{B. Customer Satisfaction}

Customer satisfaction has been transformed into a compulsory vocabulary for every business and nonprofit organization, business consultant, marketing researcher, business executive and in a particular context. Many experts reveal or explain about customer satisfaction.

According to Abdullah and Tantri (2012: 38) explaining satisfaction is the level of one's feelings after comparing the performance of the product (result) that he felt with hope.

So the level of satisfaction is a function of tie the difference between perceived performance and expectations. Customers can experience one of three common papal levels. If performance is below expectations, customers will be dissatisfied. If performance seseuai with expectations, customers will be satisfied, if performance exceeds expectations, customers will be very satisfied, happy, or happy (Abdullah and Tantri, 2012: 38). 
.......tler and Lane, (2009: 318) In general Satisfaction (satisfaction) is the feeling of pleasure or disappointment of someone who arises because it compares the perceived performance of products (results) to their expectations.

\section{Customer Loyalty}

Sangadji and Sopiah (2013: 104) define customer loyalty expressed by Grifin (2005) which states that "loyality is defined as non-random purchase expressed over time dicision making unit". Based on the definition can be explained that loyalty refers more to the behavior of decision-making units to make a continuous purchase of goods or services of a selected company.

Sangadji and Sopiah (2013: 104) declare that loyalty is a deeply enduring commitment of customers to re-subscribe or re-purchase consistent products or services consistently in the future, although the influence of marketing situations and efforts has the potential to cause behavioral change .

Parasuraman (2005) also defines customer loyalty in the service marketing konkteks as a response closely related to a pledge or a pledge to uphold the commitment to the continuity of the relationship, and is usually reflected in the ongoing purchase of the same service provider on the basis of dedication and pragmatic constraints.

Sangadji and Sopiah (2013: 104) state that customer loyalty is a customer commitment to a brand, a supplier, based on a very positive attitude and reflected in consistent repeat purchases.

From the above definition it can be seen that loyalty is more aimed at a behavior, which is shown by regular purchases and is based on decision-making units.

Figure 1. Conceptual Framework

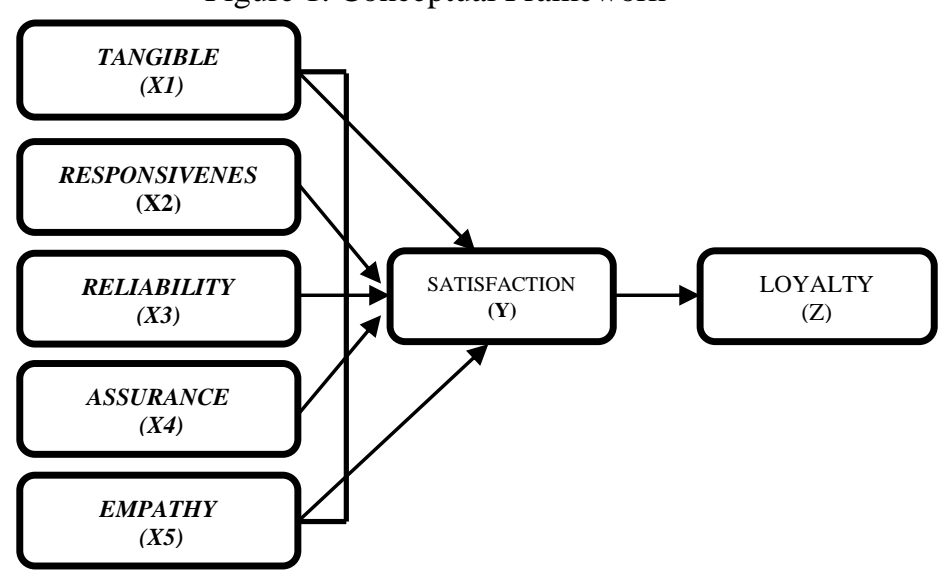

\section{RESEARCH METHOD}

Type of research is quantitative research using survey method. The location of this research is done in CV. Sempati Star Jalan Pondok Kelapa Dormitory, No. 19-20, Medan City of North Sumatra. This research will be conducted from March 2017 until June 2017.

Data used in this study are:

\section{a) Primary Data}

Primary data is data obtained through direct observation of the observable symptoms of the research object. Primary data obtained by interview, observation and distributed questionnaires (research questionnaire) to the research object and filled in directly.

b) Secondary data

Secondary data is data obtained from documents and journals, books, literature and written reports of companies, existing in the company and parts of materials or writings that have to do with the problem under study.
Operational Definition

1. Quality of Service is the ability of the company to meet customer needs and desires in accordance with customer expectations. In this study the quality of service consists of:

1) Physical evidence (Tangibles) (X1) is the attraction of the physical facilities, equipment, and materials used by the company, as well as the employee's appearance or concrete evidence of the services provided by the company.

2) Responsiveness (X) is the ability of employees to help customers quickly and respond to their requests, and to inform when services will be delivered and then provide services quickly.

3) Reliability (Reliability) (X3) is, the ability of the company to provide accurate and reliable service (in accordance with the time as promised).

4) Assurance (X4) is the company's ability to grow customer's trust in the company.

5) Empathy $(\mathrm{X})$ is the company understands the problems of its customers and gives attention to customers without being picky. to its customers and have a comfortable operating hours.

2. Transport Service User Satisfaction (Y) is the feeling of pleasure or disappointment of a person arising from comparing the perceived performance of the product (outcome) to their expectations.

3. User Loyalty of Transportation Service (Z) is a person's behavior or commitment in making a decision to make a continuous purchase of goods or services of a selected company.

The number of samples in this study as many as 100 respondents. Methods of data collection is done by observation, interview, questionnaire. Data analysis method is done by data analysis of path diagram (path analysis).

\section{RESULTS AND DISCUSSION}

\section{A. Validity and ReliabilityTest}

Validity test results throughout the questions this study declared invalid. Reliability testing which states that the instrument variables in this study is reliable.

B. Classical Assumption Test

a. Normality Test

Normality test results are as follows:

Figure 2. PP-Plot Graphs

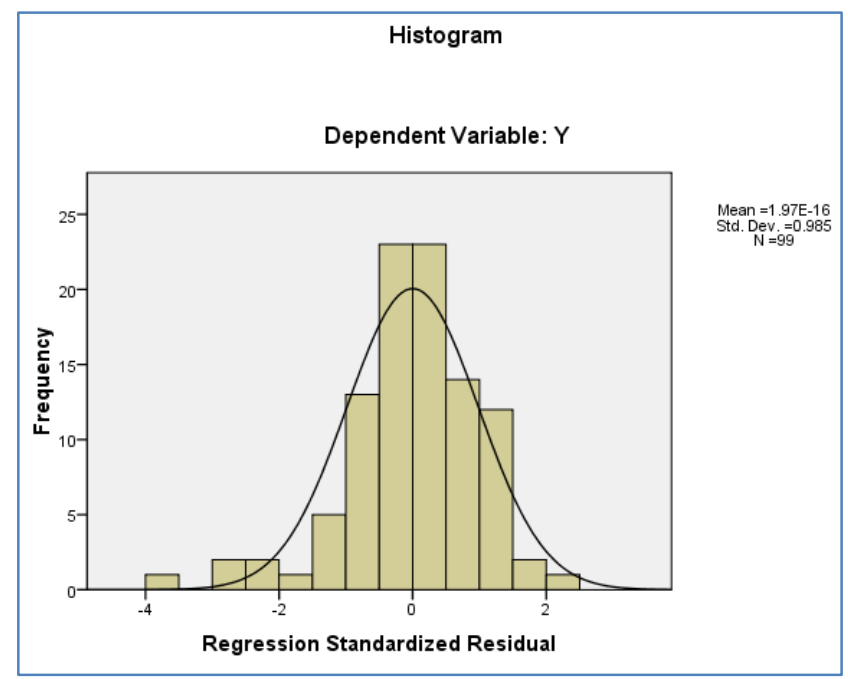


histogram of the data residuals follow a normal distribution pattern distribution histogram which approximates the shape of a bell.

b. Multicollinearity Test

Multicollinearity test results can be seen in the following table:

TABLE 4

RESULTS MULTICOLLINEARITYTEST

\begin{tabular}{|ll|r|c|}
\hline Model & \multicolumn{2}{|c|}{ Collinearity Statistics } \\
\cline { 3 - 4 } & & Tolerance & \multicolumn{1}{c|}{ VIF } \\
\hline 1 & (Constant) & & \\
& Tangible (X1) &, 360 & 2,775 \\
& Responsive (X2) &, 588 & 1,702 \\
& Reability (X3) &, 503 & 1,988 \\
& Assurance (X4) &, 496 & 2,014 \\
& Empaty (X5) &, 499 & 2,005 \\
& Kepuasan (Y) &, 269 & 3,713 \\
\hline
\end{tabular}

a. Dependent Variable: Loyalitas (Z)

REGRESSION COEFFICIENTS IN EQUATION MODELS I

Coefficients $^{\mathrm{a}}$

\begin{tabular}{|c|c|c|c|c|c|c|}
\hline \multirow{2}{*}{\multicolumn{2}{|c|}{ Model }} & \multicolumn{2}{|c|}{$\begin{array}{c}\text { Unstandardized } \\
\text { Coefficients } \\
\end{array}$} & \multirow{2}{*}{\begin{tabular}{|c|}
$\begin{array}{c}\text { Standardized } \\
\text { Coefficients }\end{array}$ \\
Beta \\
\end{tabular}} & \multirow[b]{2}{*}{$t$} & \multirow[b]{2}{*}{ Sig. } \\
\hline & & B & Std. Error & & & \\
\hline \multirow[t]{6}{*}{1} & (Constant) & 936 & 1,028 & & ,911 & ,365 \\
\hline & Tangible (X1) & 282 & 073 & 319 & 3,843 &, 000 \\
\hline & Responsive & 167 & , 080 & ,142 & 2,079 & , 040 \\
\hline & Reability (X3) & 171 & 082 & 153 & 2,074 & ,041 \\
\hline & Assurance (X4) & ,179 & ,081 & , 165 & 2,223 & ,029 \\
\hline & Empaty (X5) & 377 & 然, & 277 & 3,946 & , 000 \\
\hline
\end{tabular}

a. Dependent Variable: Kepuasan $(Y)$

From Table 5 the above coefficient (in the standardize Coeeficients column) the regression coefficient values are:

1. Tangible Coefficient (X1) is P1 of 0.319 (hence this value is inserted into the path analysis diagram).

2. The coefficient of responsiveness (X2) is $\mathrm{P} 2$ of 0.142 (hence this value is entered into the path analysis diagram).

3. Reliability coefficient (X3) is P3 of 0.153 (hence this value is entered into the path analysis diagram).

4. The coefficient of Assurance (X4) is P4 of 0.165 (hence this value is entered into the path analysis diagram).

Table 4 provides information thattolerance values> 0.1 means that there were no symptoms of multicollinearity. Similarly, $\quad$ VIF(VarianceInflationFactors) $<5.0 \quad$ means no symptoms multikolinieritas.

c. HeterokedastisitasTest

Heterokedastisitas test results can be seen in the following table:

Figure 3. ScatterplotGraph

Scatterplot

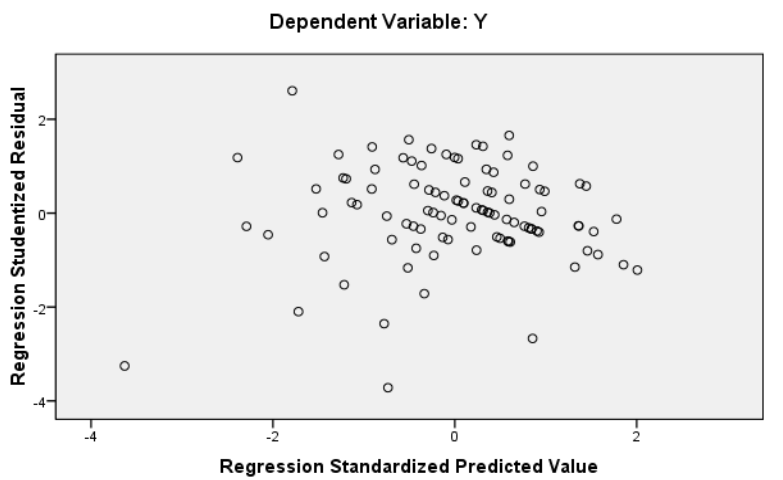

Figure 5 provides athat the distribution of residual information is homokedastisitas wherein the data on the graph shows the distribution of the data residual evenly all over the place without forming a specific pattern. Thus it can be said that this model is a good model and free from problems heterokedastisitas.

\section{Path Analysis}

1. The Regression Coefficient in Equation Model I:

The regression in equation I (direct influence X1, X2, X3, $\mathrm{X} 4, \mathrm{X}$, against $\mathrm{Y}$ ) is used to determine the values of $\mathrm{P} 1, \mathrm{P} 2$, $\mathrm{P} 3, \mathrm{P} 4, \mathrm{P} 5$, and $\mathrm{P} \varepsilon 1$. The model equation is:

$\mathrm{Y}_{1}=\mathrm{P}_{1} \mathrm{X}_{1}+\mathrm{P}_{2} \mathrm{X}_{2}+\mathrm{P}_{3} \mathrm{X}_{3}+\mathrm{P}_{4} \mathrm{X}_{4}+\mathrm{P}_{5} \mathrm{X}_{5}+\mathrm{P} \varepsilon_{1}$

5. The Empaty coefficient (X5) is P5 of 0.277 (hence this value is entered into the path analysis diagram).

TABLE6

Model Summary

\begin{tabular}{|c|r|r|r|r|}
\hline Model & $\mathrm{R}$ & $\mathrm{R}$ Square & $\begin{array}{c}\text { Adjusted R } \\
\text { Square }\end{array}$ & $\begin{array}{c}\text { Std. Error of the } \\
\text { Estimate }\end{array}$ \\
\hline 1 &, $855^{\mathrm{a}}$ &, 731 &, 716 & 1,03539 \\
\hline
\end{tabular}

a. Predictors: (Constant), Empaty (X5), Reability (X3), Respon

b. Dependent Variable: Kepuasan (Y)

In Table 6, the Summary Model shows that the value of Adjusted R-Square is 0.716 , it shows that the contribution of variation of service quality value in influencing variation of respondent satisfaction is $71,6 \%$, the rest is contribution of other variable not included in this research model. This value can be used to determine the value of the path coefficient with the residual, namely: $P \varepsilon 1=\sqrt{ }\left(1-R^{2} 1\right)=\sqrt{ }(1-0,716)=0,846$ (hence this value is inserted into the path analysis diagram).

Figure 4. Regression in Equation Model I

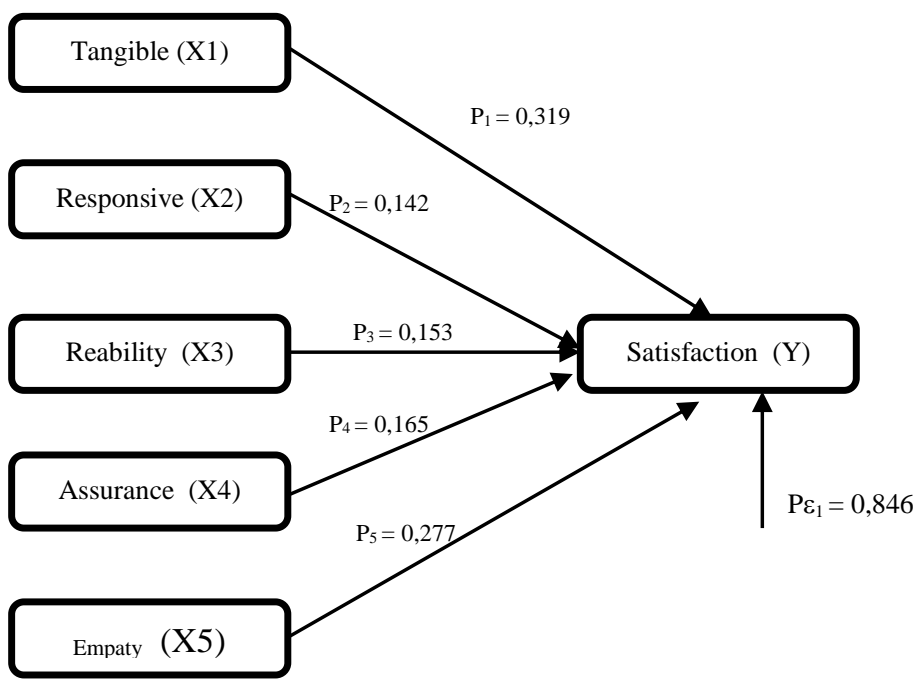

So the equation is:

$\mathrm{Y}_{1}=\mathrm{P}_{1} \mathrm{X}_{1}+\mathrm{P}_{2} \mathrm{X}_{2}+\mathrm{P}_{3} \mathrm{X}_{3}+\mathrm{P}_{4} \mathrm{X}_{4}+\mathrm{P}_{5} \mathrm{X}_{5}+\mathrm{P} \varepsilon_{1}$

$\mathrm{Y} 1=0,319 \mathrm{X} 1+0,142 \mathrm{X} 2+0,153 \mathrm{X} 3+0,165 \mathrm{X} 4+0,277 \mathrm{X} 5+0,846 \varepsilon 1$ 
............ Coefficient in Equation Model II:

Regression in equation model II (direct influence X1, X2, $\mathrm{X} 3, \mathrm{X} 4, \mathrm{X} 5$, against $\mathrm{Z}$ ) is used to determine the values of $\mathrm{P} 6$, P7, P8, P9, P10, P11 and Pe2. The model equation is: $\mathrm{Y}_{2}=\mathrm{P}_{6} \mathrm{X}_{1}+\mathrm{P}_{7} \mathrm{X}_{2}+\mathrm{P}_{8} \mathrm{X}_{3}+\mathrm{P}_{9} \mathrm{X}_{4}+\mathrm{P}_{10} \mathrm{X}_{5}+\mathrm{P}_{11} \mathrm{Y}+\mathrm{P} \varepsilon_{2}$

Table7

Regression Coefficient in Equation Model II

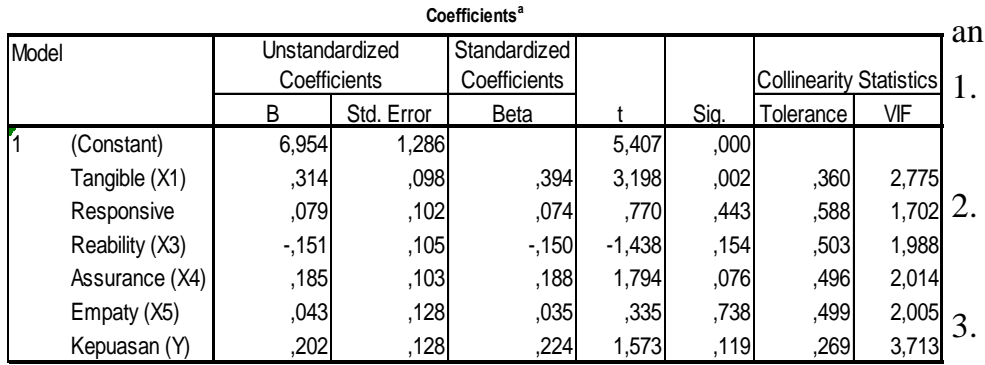

a. Dependent Variable: Loyalitas (Z)

From Table 7 the above coefficient (in the standardize Coeeficients column) the regression coefficient values are:

1. The tangible coefficient (X1) is P6 of 0.394 (hence this value is entered into the path analysis diagram).

2. The coefficient of responsiveness (X2) is P7 of 0.074 (hence this value is incorporated into the path analysis diagram).

3. The reliability coefficient (X3) is P8 of -0.150 (hence this value is entered into the path analysis diagram).

4. The assurance coefficient (X4) is P9 of 0.188 (hence this value is incorporated into the path analysis diagram).

5. The foury coefficient (X5) is P10 of 0.035 (hence this value is entered into the path analysis diagram).

6. The satisfaction coefficient (Y) is $\mathrm{P} 11$ of 0.224 (hence this value is entered into the path analysis diagram).

\section{Table8}

\begin{tabular}{|l|c|r|r|rr|}
\hline Model & R & R Square & $\begin{array}{c}\text { Adjusted R } \\
\text { Square }\end{array}$ & Std. Error of the Estimate \\
\hline 1 &, $700^{\mathrm{a}}$ &, 491 &, 458 & & 1,28982 \\
\hline
\end{tabular}

\section{b. Dependent Variable: Loyalitas (Z)}

While from Table 8 Summary Model shows Adjusted RSquare value is 0,458 , it shows that contribution of variation of service quality and satisfaction value in influencing variation of loyalty is $45,8 \%$, the rest is contribution of other variable not included in this research model. This value can be used to determine the value of the path coefficient with residual:P $\mathrm{E} 1=$ $\sqrt{ }\left(1-R^{2} 1\right)=\sqrt{ }(1-0,458)=0,736$ (then this value is inserted into the path analysis diagram).

Figure 5. Regression in Equation Model II

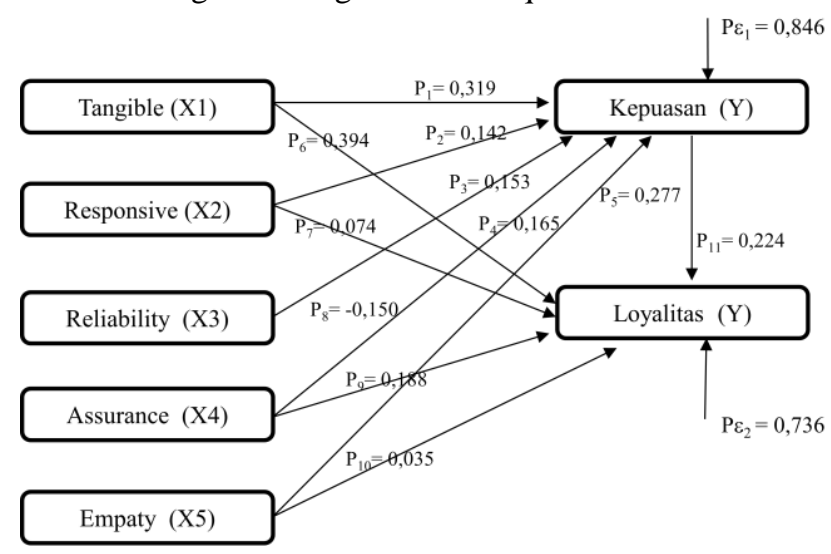

So the equation is:

$\mathrm{Z}=\mathrm{P}_{6} \mathrm{X}_{1}+\mathrm{P}_{7} \mathrm{X}_{2}+\mathrm{P}_{8} \mathrm{X}_{3}+\mathrm{P}_{9} \mathrm{X}_{4}+\mathrm{P}_{10} \mathrm{X}_{5}+\mathrm{Y}+\mathrm{P} \varepsilon_{2}$

$Z=0,394 X_{1}+0,074 X_{2}--0,150 X_{3}+0,188 X_{4}+0,035 X_{5}+$ $0,224 \mathrm{Y}+0,736 \varepsilon_{2}$

\section{CONCLUSION}

The results of research conducted hypothesis is able to answer the following conclusion:

Tangible partially have a positive and significant influence on the user satisfaction of CV Sempati Star Bus service

2. Responsiveness partially have a positive and significant impact on user satisfaction of CV bus services. Sempati Star.

3. Reliability partially has a positive and significant impact on the user satisfaction of CV Sempati Star bus service.

4. Assurance partially has a positive and significant impact on user satisfaction of CV bus services. Sempati Star.

5. Empaty partially have a positive and significant impact on user satisfaction of CV bus services. Sempati Star.

6. Tangible effect directly on loyalty. Satisfaction is not an intervening variable mediating tangible relationships with loyalty.

7. Responsiveness directly affects loyalty. It appears that satisfaction is not an intervening variable mediating the responsiveness relationship with loyalty.

8. Reliability directly affects loyalty. Satisfaction is not an intervening variable mediating reliability relationship with loyalty.

9. Assurance directly affects loyalty. Satisfaction is not an intervening variable mediating the relationship of assurance with loyalty.

10. Empaty indirect effect on loyalty but must be through satisfaction, satisfaction is intervening variable mediate empaty relationship with loyalty. Satisfaction mediates the relationship of empathy with loyalty

11. Partial satisfaction has a positive and significant impact on the loyalty of service users of CV bus. Sempati Star.

12. Tangible, responsiveness, reliability, assurance, empathy and satisfaction simultaneously (together) have a positive and significant effect on loyalty variable of $\mathrm{CV}$ bus service user. Sempati Star.

\section{References}

[1] Tjiptono Fandy. 2007. Manajemen Jasa. Jakarta: Andi.

[2] Abdullah Thamrin dann Tantri Francis. 2012. Manajemen Pemasaran. Jakarta: Rajawali Pers.

[3] Assauri Sofjan. 2015. Manajemen Pemasaran. Jakarta: Rajawali Pers.

[4] Mardikawati Woro dan Farida Naili. 2013.Pengaruh Nilai Pelanggan Dan Kualitas Layanan Terhadap Loyalitas Pelanggan, Melalui Kepuasan Pelanggan Pada Pelanggan Bus Efisiensi (Studi PO Efisiensi Jurusan Yogyakarta-Cilacap).Jurnal Administrasi Bisnis, Volume 2, Nomor 1, Maret 2013.

[5] Meitiana. 2014. Pengaruh Kualitas Layanan Terhadap Loyalitas Melalui Kepuasan Konsumen Pengguna Jasa Transportasi Udara Rute Palangka Raya - Jakarta.JSM (Jurnal Sains Manajemen). ISSN : 2302-1411. Volume III, Nomor 1, April 2014.

[6] Tjiptono Fandy. 2012. Service Management Mewujudkan Layanan Prima. Edisi Dua. Jakarta: Andi.

[7] Putri Wury Indahsari. 2014 . Pengaruh Kualitas Pelayanan Terhadap Kepuasan Konsumen Serta Citra Perusahaan Dalam Membangun Loyalitas Konsumen PT. KAI. E-Journal Graduate Unpar. Part A : Economics. Vol. 1, No. 2. Tahun 2014. ISSN: 2355-4304.

[8] Atsatalada Nanda dan Mudiantono, 2012. Analisis Pengaruh Kualitas Pelayanan Terhadap Kepuasan Konsumen Dan Dampaknya Pada Loyalitas Konsumen Dalam Menggunakan Jasa Transportasi PO Sumber Alam (Studi Kasus Pada Penumpang Bus Sumber Alam Jurusan Yogyakarta-Jakarta). Diponegoro Journal Of 
http://ejournal-s1.undip.ac.id/index.php/djom.

[9] Yulianingsih Dian Kurnia, Hidayat Wahyu dan Budiatmo Agung. 2013. Pengaruh Kualitas Pelayanan Dan Kepuasan Pelanggan Terhadap Loyalitas Pelanggan (Studi Kasus Pada Pengguna Jasa Transportasi Bpu. Rosalia Indah). Jurnal Ilmu Administrasi Bisnis. Volume 2, Nomor 2, Tahun 2013.

[10] Iskandar Priasmoro dan Tri Indra Wijaksana. 2015. Pengaruh Kualitas Pelayanan Terhadap Loyalitas Pelanggan Melalui Kepuasan Sebagai Variabel Intervening Pada Pengguna Jasa Transportasi Pt. Tara Megah Muliatama (Taksi Gemah Ripah) Di Kota Bandung. Jurnal Prodi Ilmu Administrasi Bisnis, Fakultas Komunikasi dan Bisnis, Universitas Telkom. openlibrary.telkomuniversity.ac.id

[11] Marismiati dan Hadiwijaya Hendra. 2013. Kualitas Pelayanan Terhadap Kepuasan Pelanggan Jasa Brt Transmusi Palembang. Jurnal Ekonomi Dan Informasi Akuntansi (JENIUS). Vol. 3 No. 3. Sept 2013.

[12] Esmaeili Ali Akbar, Monireh Aryaee Manesh dan Ebrahim Golshan. 2013. Service Quality, Customer Satisfaction and Customer Loyaltyin RAJA Rail Transportation Company. International Research Journal of Applied and Basic Sciences (IRJABS) online at www.irjabs.com. ISSN 2251-838X / Vol, 5. Science Explorer Publications Tahun 2013.

[13] Basir Muhammad, Basri Modding, Jeni Kamase dan Sabri Hasan. 2015. Effect of Service Quality, Orientation Services and Pricing on Loyalty and Customer Satisfaction in Marine Transportation Services. International Journal of Humanities and Social Science Invention ISSN (Online): 2319- 7722, ISSN (Print): 2319-7714. www.ijhssi.org Volume 4 Issue 6. June. 2015.

[14] Hu Kai Chieh and Huang Mei Chieh. 2011. Effects of Service Quality, Innovation and Corporate Image on Customer's Satisfaction and Loyalty of Air Cargo Terminal. International Journal of Operations Research ( IJOR) Vol.8, No. 4. Tahun 2011.

[15] Sangadji, E.M. dan Sopiah. 2013. Prilaku Konsumen: Pendekatan Praktis Disertai:Himpunan Jurnal Penelitian. Yogyakarta: Andi.

[16] Kotler, Philip Dan Kevin Lane Keller. 2007. Manajemen Pemasaran. Edisi Kedua Belas. Jakarta: Indeks.

[17] Lupiyoadi, Rambat. 2008. Manajemen Pemasaran jasa. Edisi Pertama. Jakarta. Salemba Empat.

[18] Sunyoto Danang dan Susanti Fathonah Eka. 2015. Manajemen Pemasaran Jasa. Cetakan Pertama. Yogyakarta : Caps.

[19] Nurlinda R.A.. 2013. Pengaruh Customer Satisfaction Strategy Terhadap Peningkatan Kepuasan Konsumen. Forum Ilmiah Volume 10 Nomer 2, Mei 2013.

[20] Nurullaili. 2013. Analisis Faktor-Faktor Yang Memengaruhi Loyalitas Konsumen Tupperware (Studi Pada Konsumen Tupperware di Universitas Diponegoro). Jurnal Administrasi Bisnis, Volume 2, Nomor 1, Maret 2013.

[21] Griffin, J, 2005 Customer's Loyalty Management, CV. Mandar Maju, Bandung

[22] Marina Sandriana, dkk. 2014. Pengaruh Kualitas Pelayanan terhadap Loyalitas Pelanggan pada Perusahaan Penerbangan Full Service AirlinesThe Effect of Service Quality on Customers Loyalty in Full Service Airlines. Jurnal Manajemen Transportasi \& Logistik (JMTransLog) - Vol. 01 No. 02, Juli 2014. ISSN 2355-4721.

[23] Sukmawati Kartika. 2011. Pengaruh Kualitas Layanan, Harga, Dan Kepuasan Pelanggan terhadap Loyalitas Pelanggan Jasa Transportasi Kereta Api Eksekutif. Naskah Publikasi. Universitas Gunadarma. Jakarta. http://publication.gunadarma.ac.id

[24] Munisih Siti dan Soliha Euis. 2015. Pengaruh Kualitas Produk Terhadap Nilai Pelanggan Dan Kepuasan Pelanggan Dan Dampaknya Pada Loyalitas Pelanggan Apotek Dela Semarang. Prosiding Seminar Nasional \& Call For Papers Fakultas Ekonomika Dan Bisnis Kinerja Perbankan, Bisnis dan Ekonomi Indonesia Universitas Stikubank Semarang Menghadapai Asean Economic Community 2015.

[25] Sugiyono. 2012. Metode Penelitian Bisnis. Bandung: Alfabeta

[26] Arikunto Suharsimi. 2010. Prosedur Penelitian Suatu Pendekatan Praktek. Jakarta: Rineka Cipta.

[27] Riduwan dan Kuncoro Engkos Achmad. 2012. Cara Menggunakan dan Memaknai Path Analysis(Analisis Jalur). Bandung. Alfabeta.

[28] Ghozali, Imam. 2011. Aplikasi Analisis Multivariate Dengan Program SPSS. Semarang.

[29] Griffin, 2007, Customer Loyalty, edisi revisi dan terbaru, Erlangga Jakarta.

[30] Lisdayanti Annisa. 2015. Upaya Meningkatkan Loyalitas Konsumen Melalui Kualitas Pelayanan Pt. Go-Jek Indonesia Cabang Bandung. Proceeding Seminar Nasional \& Call for Papers (SCA 5). Vol 5, No. 1. Fakultas Ekonomi Dan Bisnis Universitas Jenderal Sudirman.

[31] Harpadeles Ian. 2016. Pengaruh Kualitas Pelayanan Dan Nilai Pelanggan Terhadap Kepuasan Dan Loyalitas Pelanggan Trans
Metro Pekanbaru. Jurnal Online Mahasiswa Fakultas Ekonomi. Universitas Riau. Vol. 3 No.1.

[32] Riyadi. 2000. Gerbang Pemasaran, Gramedia, Jakarta

[33] Lupiyoadi, R dan A. Hamdani. 2009. Manajemen Pemasaran Jasa. Edisi 2. Salemba Empat. Jakarta.

[34] Maulana M. Istifau, Suryoko Sri , Prabawani Bulan. 2016. Pengaruh Kualitas Pelayanan Dan Harga Terhadap Loyalitas Pelanggan Melalui Kepuasan Pelanggan Sebagai Variabel Intervening (Studi Kasus Pada Bus Po. Nusantara Jurusan Solo Jakarta). Jurnal Ilmu Administrasi Bisnis Volume 5, Nomor 1, Tahun 2016.

[35] Taslim Bahar. 2013. Kualitas Pelayanan Dan Loyalitas Penggunaan Ojek Sepedamotor Sebagai Angkutan Umum Penumpang Perkotaan. Jurnal Untad. Majalah Ilmiah Maktek. Vol 15 , No 2 (2013).

[36] Petra Surya Mega Wijaya dan Jonathan Herdioko. 2010. Pengaruh Kualitas, Persepsi Nilai, Citra, Dan Kepuasan Terhadap Loyalitas Atau Keinginan Berpindah Penumpang Bus Transjogja. JRMB, Volume 5, No. 2, Desember 2010. 